DOI: https://doi.org/10.32836/2521-666X/2018-1-59-27

УДК 336.225.674(477)

\title{
Ткач О.Л.
}

здобувач,

Одеський національний економічний університет

\section{СУЧАСНІ ПРОБЛЕМИ РОЗВИТКУ ДЕРЖАВНОГО ФІНАНСОВОГО АУДИТУ В УКРАЇНІ}

Сталий розвиток державного фінансового контролю є неможливим без якісного інформаційного забезпечення, яке можна сформувати тільки за умови вирішення сучасних проблемних аспектів теорії, методики, організації державного фінансового контролю. Для досягнення цієї мети в роботі розглянуто проблеми організаційного характеру (відсутність чіткого переліку органів, на яких покладено здійснення в Україні державного фінансового аудиту, та їх повноважень), правового характеру (неоднозначність чинного законодавства у сфері державного фінансового контролю), методологічного характеру (недостатність теоретичних і методологічних основ проведення державного фінансового аудиту), проблеми кадрового потенціалу. Доведена необхідність удосконалення системи державного фінансового аудиту шляхом послідовної реалізації заходів, спрямованих на побудову сучасної моделі, яка б відповідала потребам національної економіки та вимогам Європейського Союзу.

Ключові слова: державний фінансовий контроль, проблема, методологія, організація, законодавчі акти, удосконалення.

Устойчивое развитие государственного финансового контроля невозможно без качественного информационного обеспечения, которое можно сформировать только решением современных проблемных аспектов теории, методики, организащии государственного финансового контроля. Для достижения этой цели в работе рассмотрены проблемы организационного характера (отсутствие четкого перечня органов, на которые возложено осуществление в Украине государственного финансового аудита, и их полномочий), правового характера (неоднозначность действующего законодательства в сфере государственного финансового контроля), методологического характера (недостаточность теоретических и методологических основ проведения государственного финансового аудита), проблемы кадрового потенциала. Доказана необходимость усовершенствования системы государственного финансового аудита путем последовательной реализачии мер, направленных на построение современной модели, соответствующей потребностям национальной экономики и требованиям Европейского Союза.

Ключевые слова: государственный финансовый контроль, проблема, методология, организация, законодательные акты, совершенствование.

\section{Tkach O.L. CURRENT PROBLEMS OF DEVELOPMENT OF PUBLIC FINANCIAL AUDIT IN UKRAINE}

Sustainable development of state financial control is impossible without qualitative information support, which can only be formulated by solving contemporary problem aspects of theory, methodology, organization of state financial control. In order to achieve this goal, the problems of organizational, legal, methodological character, problems of personnel potential are considered in the work. The problems of organizational character today include the lack of a clear list of powers of the state financial audit bodies, the existence of functional duplication, excessive control overloads of certain control objects. In the light of legal issues, one should highlight the frequent change and ambiguity of legislative and other normative legal acts, which leads to the spread of fraud and fraud in the sphere of budget funds and state property. Problems of personnel potential are manifested through low wages and a significant amount of business trips. The necessity of improving the system of state financial audit is proved by developing measures aimed at constructing a modern model that meets the needs of the national economy and the requirements of the European Union. These measures include: development of uniform conceptual foundations of the organization of the state financial audit, standardization of forms and methods of control activity; a doption of standards for the implementation of the state financial audit to create an effective mechanism for counteracting offenses and abuses in the use of budget funds, state and communal property; optimization of the organizational structure, clarification and delineation of functions of the bodies of 
state financial audit; observance of international principles of financial audit at the state and regional levels, adaptation of the system of state financial audit to European requirements; introduction of preventive forms of state financial audit in the work of controlling entities; improvement of personnel support; improvement of material and technical, scientific and informational and analytical support for the functioning of the state financial audit system; organization of internal audit work; creation of a unified automated information and analytical base in the field of state financial audit; use of the risk-oriented approach when selecting audit objects among organizations and enterprises using budget financial resources or state property; increasing the responsibility of managers at all levels of government and clearly setting its boundaries in the law.

Key words: state financial control, problem, methodology, organization, legislative acts, perfection.

Постановка проблеми. Чинна нині в Україні система державного фінансового аудиту має низку неузгодженостей, що потребують негайного вирішення: організаційних, правових, методологічних, а також незабезпеченість кадровим потенціалом.

Аналіз останніх досліджень і публікацій. Серед наукових досліджень вітчизняних учених, у яких висвітлено проблеми розвитку державного фінансового аудиту, варто звернути увагу на праці М.Т. Білухи, Ф.Ф. Бутинця, Н.Г. Виговської, П.К. Германчука, Л.В. Гуцаленко, В.А. Дерія, Н.І. Дорош, Є.В. Кагюги, M.M. Каленського, М.М. Коцупатрого, Н.І. Рубан, І.Б. Стефанюка, І.Ю. Чумакової й інших. Незважаючи на те, що проблематиці розвитку державного фінансового аудиту в Україні на сучасному етапі ученими приділено досить багато уваги, питання концептуального, теоретико-методологічного, організаційного характеру й надалі залишаються актуальними.

Мета статті полягає в дослідженні проблемних аспектів функціонування державного фінансового аудиту в Україні.

Виклад основного матеріалу. На сучасному етапі розвитку державного фінансового аудиту в Україні $\epsilon$ низка прогалин організаційного, правового, методологічного та кадрового характеру, без вирішення яких неможливий ефективний розвиток державного фінансового аудиту.

Насамперед йдеться про групу проблем організаційного характеру, а саме: відсутність чіткого переліку органів, на яких покладено здійснення в Україні державного фінансового аудиту, та їх повноважень. Зокрема, державний фінансовий аудит, як правило, пов'язують із Рахунковою палатою України,
Державною аудиторською службою України, Міністерством фінансів України, Державною службою фінансового моніторингу України, Фондом державного майна України, Національним банком України, Антимонопольним комітетом України, службами внутрішнього контролю у міністерствах та інших центральних органах виконавчої влади.

Але, незважаючи на те, що Конституцією України та чинними нормативно-правовими актами частково регламентовано повноваження та функції цих органів у сфері державного фінансового аудиту, загального рамкового нормативно-правового акта, який би визначав завдання того чи іншого виду контролю й моделював систему контролюючих інституцій відповідно до поставлених завдань, зараз немає. Наслідком цього є дублювання та паралелізм у роботі контролюючих органів різних рівнів, надмірне перевантаження деяких об'єктів контрольними заходами. При цьому значна частина державних за природою грошових потоків залишається безконтрольною.

До другої групи слід віднести проблеми правового характеру. Так, чинне в Україні бюджетне та фінансове законодавство має чимало прогалин і слабких місць, що приводить до поширення махінацій і шахрайства у сфері бюджетних коштів і державного майна. Однією 3 причин таких юридичних колізій $\epsilon$ недостатня участь контролюючих органів у процесі розробленгня нових і вдосконалення наявних нормативно-правових актів щодо державного фінансового аудиту, формування, розподілу та використання бюджетних коштів, здійснення заходів із запобігання фінансових порушень. 
Суттєвим недоліком функціонування державного фінансового аудиту $є$ відсутність законодавчого акту про державний фінансовий аудит, яким би було чітко визначено:

- сутність державного фінансового аудиту, його мету, завдання та функції;

- предмет та об'єкти державного фінансового аудиту;

- принципи та вимоги до проведення державного фінансового аудиту;

- види державного фінансового аудиту, методи та форми його проведення;

- суб'єктів державного фінансового аудиту, їхні функції, завдання, розмежування повноважень і відповідальності між ними, а також чітко розмежовано та закріплено контрольні заходи за Рахунковою палатою України та Державною аудиторською службою України;

- порядок взаємодії суб'єктів контролю між собою та правоохоронними органами, органами влади та управління;

- функції фінансових органів та органів Державної казначейської служби України відповідних рівнів бюджету щодо здійснення попереднього та поточного аудиту на стадіях формування кошторисів доходів і видатків бюджетних установ та їх використання.

Третя група складається 3 проблем методологічного характеру. Одна 3 них - відсутність базової методології проведення державного фінансового аудиту (специфічних процесуальних норм) і слабкість їі теоретичних і методологічних основ, що спричиняе масові фінансові порушення в Україні. Водночас відсутність специфічних процедурних стандартів здійснення державного фінансового аудиту приводить до безсистемності та хаотичності у підходах контролюючих органів до трактування аналогічних правопорушень і визначення відповідальності за них. Крім цього, до цієї групи проблем слід віднести незабезпечення комплексності контролю, тобто відповідності попереднього, поточного та наступного аудиту. За результатами діагностики функціонування сучасної системи державного фінансового аудиту в Україні виявлено, що нині державний фінансовий аудит переважно здійснюється контролюю- чими органами у вигляді контрольно-аналітичних та попереджувально-профілактичної функції він практично не виконує. Адже органи системи державного фінансового аудиту здебільшого констатують факти правопорушення і вживають заходи щодо їх усунення. Таким чином попередній і поточний контроль просто нівелюються.

Четвертою групою причин слабкості чинної системи державного фінансового аудиту $\epsilon$ проблеми кадрового потенціалу. Через досить невисокий рівень заробітної плати, умови праці та наявність значної кількості відряджень спостерігається неукомплектованість контролюючих органів кадрами. Також $є$ проблеми в організації професійної підготовки та перепідготовки кадрів, що $є$ наслідком браку необхідних підручників, недосконалості методичної літератури, незабезпеченості набуття майбутніми працівниками належного практичного досвіду під час навчання, відсутності тісної взаємодії між контролюючими органами та закладами освіти щодо підготовки, перепідготовки та підвищення кваліфікації кадрів тощо.

Наявна ситуація свідчить про те, що система державного фінансового аудиту в Україні не забезпечує належного рівня виконання державою своїх повноважень у частині здійснення контролю за формуванням, розподілом і використанням державних коштів. Такий стан справ приводить до зростання кількості й обсягів фінансових правопорушень, а отже - до розкрадання державних коштів.

Для удосконалення державного фінансового аудиту, підвищення рівня ефективності його здійснення необхідно забезпечити:

- розроблення єдиних концептуальних засад організації державного фінансового аудиту, стандартизацію форм і методів контрольної діяльності;

- прийняття стандартів здійснення державного фінансового аудиту для створення дієвого механізму протидії правопорушенням і зловживанням у сфері використання бюджетних коштів, державного та комунального майна; 
- оптимізацію організаційної структури, уточнення і розмежування функцій органів державного фінансового аудиту;

- дотримання міжнародних принципів фінансового аудиту на державному та регіональному рівнях, адаптацію системи державного фінансового аудиту до європейських вимог;

- впровадження превентивних форм державного фінансового аудиту в роботу контролюючих суб'єктів;

- удосконалення кадрового забезпечення системи державного фінансового аудиту (підготовка, перепідготовка та підвищення кваліфікації кадрів відповідно до нових кваліфікаційних вимог та методик);

- покращання матеріально-технічного, наукового та інформаційно-аналітичного забезпечення функціонування системи державного фінансового аудиту;

- організацію роботи внутрішнього аудиту в бюджетних установах та організаціях, в органах місцевої виконавчої влади;

- посилення відповідальності керівників на всіх рівнях управління та чітке встановлення іiі меж у законодавстві;

- створення єдиної автоматизованої інформаційно-аналітичної бази у сфері державного фінансового аудиту 3 можливістю використання iï і на місцевому рівні;

- використання ризик-орієнтованого підходу під час вибору об'єктів аудиту серед бюджетних підприємств, установ, організацій і підприємств, що використовують бюджетні фінансові ресурси або державне майно.

Поряд із цим варто зазначити, що в умовах децентралізації влади та реформи місцевого самоврядування важливою $є$ побудова та схвалення на законодавчому рівні оновленої сучасної моделі системи державного фінансового аудиту на місцевому рівні, яка б відповідала вимогам Свропейського Союзу і характеризувалася такими рисами:

- зовнішній незалежний фінансовий контроль за надходженням до бюджетів усіх рівнів та витрачанням бюджетних коштів, у тому числі місцевих бюджетів та тран- сфертів, повинен здійснюватися Рахунковою палатою України та іiі регіональними представництвами;

- внутрішній фінансовий контроль за своєчасним та в повному обсязі надходженням податків, зборів (обов'язкових платежів) до бюджетів усіх рівнів - Міністерством фінансів України, зокрема Державною фіскальною службою України, а також іншими уповноваженими органами влади;

- внутрішній фінансовий контроль за витрачанням коштів місцевих бюджетів та трансфертів 3 місцевих бюджетів - внутрішніми службами контролю та аудиту у складі місцевих органів влади та аудиторами у бюджетних установах; за використанням трансфертів 3 державного бюджету місцевим бюджетам - уповноваженими представниками (державними аудиторами) Міністра фінансів України.

У 2015 році були внесені певні зміни до Закону України «Про основні засади здійснення державного фінансового контролю в Україні», які передбачували: забезпечення узгодженості законодавства у сфері проведення заходів державного фінансового аудиту органами Державної фінансової інспекції; зробити більш чітким, прозорим та зрозумілим механізм проведення заходів державного фінансового контролю органами Державної фінансової інспекції [1]. Проте ці зміни до законодавства не мали бажаного ефекту, i сьогодні є низка недоліків у діяльності системи державного внутрішнього фінансового аудиту, а саме відсутність:

- загальної процедури фінансового аудиту, переліку органів і суб'єктів, яким делеговано право на здійснення державного фінансового аудиту;

- статусу, функцій та повноважень органів і суб'єктів державного фінансового аудиту, їх взаємовідносин і підзвітності;

- повноважень вищих органів державної влади в системі фінансового аудиту; єдиного методологічного забезпечення фінансового аудиту щодо встановлення системи економічних показників, які відображають стан фінансової дисципліни, і методики їх розрахунку; 
- механізму внутрішнього контролю дотримання чинного законодавства в системі фінансового аудиту;

- недостатнє застосування в контрольно-ревізійній роботі методик, спрямованих на визначення ефективності використання державних фінансових ресурсів;

- невиконання положень чинного законодавства щодо забезпечення належної взаємодії між органами державного фінансового аудиту, що посилює дублювання та паралелізм у роботі, та ін.

У 2016 році певними нормативними змінами у діяльності державного фінансового аудиту була створена нова державна структура - Державна аудиторська служба України - відповідно до Положення про Державну аудиторську службу України [2]. Нова система контролю за державними установами та організаціями має на меті змінити порядок та організацію управління, тому після цих упроваджень передбачаються позитивні зміни у сфері державного контролю, зокрема запобігання розкраданню держаних коштів.

Внутрішній державний фінансовий аудит в Україні пройшов декілька етапів розвитку і все ще перебуває на стадії вдосконалення та трансформації 3 урахуванням надбань світової практики у сфері внутрішнього фінансового аудиту. Важливо внести низку змін у діяльність цієї інституції, зокрема доцільно вдосконалити нормативно-правову базу, методологічне та матеріально-технічне забезпечення діяльності органів державного внутрішнього фінансового аудиту, впровадити Єдину систему державного внутрішнього фінансового аудиту, що має контролювати всіх юридичних осіб.
Важливою вимогою до побудови сучасної системи державного фінансового аудиту на всіх рівнях господарювання є здійснення контролю на основі забезпечення чіткої взаємодії і координації зусиль усіх учасників фінансово-бюджетних відносин для вирішення завдань державного фінансового аудиту. Сучасна система державного фінансового аудиту повинна бути побудована таким чином, щоб можна було швидко й ефективно налаштовуватися на вирішення нових завдань та викликів. Таким чином, тільки комплексна реалізація заходів забезпечить найкращий ефект від їх запровадження.

Висновки. Отже, система державного фінансового аудиту в Україні має низку проблем та недоліків, які роблять 价 неефективною, затратною та непрозорою. Нирні не створено достатнього правового, інформаційного, організаційного, комунікативного, методологічного та кадрового забезпечення для здійснення державного фінансового аудиту. Це все негативно впливає на рівень довіри населення до влади, на розвиток фінансово-бюджетних відносин в Україні, гальмуючи низку трансформацій у цій сфері. 3 огляду на це необхідність удосконалення системи державного фінансового аудиту є особливо актуальною та нагальною. Вирішити проблеми та подолати недоліки організації та функціонування державного фінансового аудиту в Україні можливо шляхом послідовної реалізації заходів, спрямованих на побудову сучасної моделі державного фінансового аудиту, яка б відповідала потребам національної економіки та вимогам Європейського Союзу.

\section{Список використаних джерел:}

1. Про основні засади здійснення державного фінансового контролю в Україні» Закон України від 26.01.1993 р. № 2939-XII, із останніми змінами, введеними Законом України від 21.12.2017 p. № 2265-VIII URL: http://zakon.rada.gov.ua/laws/show/2939-12.

2. Положення про Державну аудиторську службу України: Постанова Кабінету Міністрів України від 03.02. 2016 р. № 43 URL: http://zakon.rada.gov.ua/laws/show/43-2016-\%D0\%BF 